\title{
COMPANY CHARACTERISTICS, DOMINANT PERSONALITIES IN BOARD COMMITTEES AND INTERNET FINANCIAL DISCLOSURES BY MALAYSIAN LISTED COMPANIES
}

\author{
ALI SALEH ALARUSSI \\ Tunku Puteri Intan Safinaz \\ School of Accountancy \\ Universiti Utara Malaysia \\ DHIAA SHAMKHI \\ Al-Zahra College for Women \\ Oman
}

\begin{abstract}
This paper investigates whether the internet financial disclosure can be explained by a company's characteristics and the dominant personalities in board committees of the Malaysian listed companies. Ten hypotheses were tested using data collected from 194 Malaysian listed companies' websites. Specifically, this paper examines the relationship between the internet financial disclosures (IFD) and the variables, namely internationality, leverage, foreign shareholders, level of technology, firm age, number of shareholders, listing status, dominant personalities in the audit committee, and chairmen of audit and nomination committees. It is found that the level of technology, firm age, number of shareholders and listing status significantly affect the level of IFD. However, the dominant personalities in the audit and nomination committees affect negatively the level of IFD in Malaysia. The study provides some evidence to support the signaling theory and the cost and benefit hypothesis in relation to internet disclosure.
\end{abstract}

Keywords: Internet reporting, dominant personalities, board committees, internationality

\section{Introduction}

Since the 90s, companies have been utilizing the Internet as a medium to disclose their information. Currently, the level of Internet disclosure varies between companies worldwide. This phenomenon has attracted many academic researchers in the disclosure field. It is argued that Internet reporting is the efficient instrument to communicate information to external users at a minimum cost. Information on the Internet can be presented in different forms of dynamic presentations such as draws, multimedia, audio, video and others (Ettredge, Richardson \& Scholz, 2002; Ashbagh, Johnstone \& Warfield, 1999; Al-Htaybat, Von \& Hutaibat,2011; Dâmaso \& Lourenço, 2011).
Despite the growing usage of the Internet by companies, professionals and practitioners, researches perceive that IFD is still in its infancy in developing countries such as Malaysia (Hassan, Jaffer \& Johi, 1999; Noor Azizi, Mahamad \& Adon, 2000; Mitchell, Ho Wern \& Pei, 2000; Khadaroo 2005, Asmah Abdulaziz, Nur Nariza \& Intan Salwani, 2011). It has been argued that some company characteristics play a significant role on the level of internet financial reporting in different countries ( e.g. Hossain, Momin \& Leo, 2012; Agyei-Mensah, 2012; Basuony \& Mohamed, 2014). Likewise, the board of directors has a significant impact on the level of financial reporting as they are the decision-makers (e.g. Gul \& Leung, 2004; Hamdan, Al-sartawi \& JaberRaed, 2013; Sanad 
\& Al-Sartawi, 2016). Therefore, this paper aims to investigate the factors that influence the extent of IFD in Malaysia. The remainder of this paper is structured as follows. Section 2 provides an overview of IFD development, while section 3 reviews the factors that affect the IFD. The research method is described in section 4. Section 5 presents the results of this research. Finally, section 6 provides the conclusions, limitations and recommendations for future research.

\section{The Development of Internet Financial Disclosure}

The nature and the extent of the disclosure problem involves a consideration of the persons to whom the disclosure is being made, an assessment of user needs and the medium of disclosure which is used to communicate with the user groups (Kreps, 1990). The main concern is that accounting reports should disclose information which is necessary to the users so that they would not be misled (Moonitz, 1961).

It has been argued that equity markets require comprehensive and transparent disclosures of the firm's value and their performance in order to run efficiently (Levitt, 1999; Richardson and Welker, 2001). Theoretically, the level of disclosure should benefit the firms by lowering the cost of capital. The decrease in the cost of capital results from two factors; first, the higher the disclosure by the firms the less transaction costs for investors and in turn creates greater liquidity of the market, improves the market value of equity and creates greater demand for the firm's securities (Diamond \& Verrecchia, 1991; Bertomeu J.,Beyer A., Dye R., 2009; Nekhili, Boubaker and Lakhal, 2012 ). Second, the additional disclosure reduces the risk estimation or the uncertainty regarding the distribution of returns (Clarkson, 1995).

Portes and Rey (2005) argue that companies started to report via the Internet as the traditional paper-based disclosure has its limitations. The increase in global investments and investors results in paper-based disclosure becoming more expensive and limited in capacity to reach investors in a timely manner. In contrast, Internet disclosure has been found to be cost effective, fast, flexible in format, and accessible to all types of users within and outside national boundaries (Debreceny, Gray \& Rahman, 2002; Nekhili, Boubaker \& Lakhal, 2012). Thus, the Internet has more advanced benefits than other media of disclosures such as newspapers, journals or other printing media. The Internet offers easy and equal access all the firm's information users and presents the image of the firm that, the firm would like to be in the eyes of the internal or external parties. Thus, the more information disclosed by a firm, the more chances the firm will be noticed by potential shareholders and investors.

In a more advanced usage of the Internet, some companies employ technological advances to display information such as streaming audio and video on their websites (Rosli Mohammed et al., 2003). Streaming audio allows interested individuals to listen to analysts' conference classes, annual meetings and similar presentations; to broadcast conference calls live; or to provide an archive of presentations from which the Internet user can select. Some companies also provide video together with the streaming audio (Hurtt, Kreuze \& Langsam, 2001).

In addition, it is argued that the investors who are concerned with return on investment will not use historical financial data as a means to evaluate companies' future performance. Instead they will search and consider recent and real-time indicators of management competence such as the ability of corporation to support and increase customer loyalty and retain and leverage the knowledge of employees (Wheeler \& Elkington, 2001).

Debreceny, Gray and Rahman (2002) argued that the primary foundation of IFD is to eliminate the notion of information asymmetry between management and ownership, supported by the view that the level of information asymmetry is an important driver of investor uncertainty. Modern corporations have adopted various mechanisms, including voluntary disclosure, to 
mitigate the effects of information asymmetry. Empirical studies on voluntary disclosure suggest that managers voluntarily enhance the visibility of their firms' financial profiles to: (a) reduce agency costs or contracting costs (Chow \& Boren, 1987); (b) reduce the cost of capital ( Botosan, 1997), (c) enhance the value of the firm (King, Pownall \& Waymire, 1990; Yeo \& Ziebart, 1995; Frankel, Johnson \& Skinner, 1999 ),(d) enhance the level of transparency (Lodhai, 2004), (e) enhance communication with the firms' stakeholders (Hassan, Jaffer \& Johi, 1999), (f) record higher market liquidity (Welker, 1995), improve the market value of equity (Nekhili , Boubaker \& Lakhal ,2012) and (g) increase the interest shown by institutions and analysts in the firm's stocks (Lang \& Lundholm, 1996; Heldin, 1999; Ali Khan, Ismail \& , Zakuan, 2013) and (h) increase the quality of financial reporting (Verawaty, 2016). IFD can also improve timeliness and verifiability. Timeliness too can be improved by increasing the frequency of disclosure, since the costs for making such disclosure is low and using devices such as hyperlinks to multiple sources of information can improve verifiability (Debreceny, Gray \& Rahman, 2002; Bertomeu et al., 2009). A study in Malaysia conducted by Ali Khan and Ismail (2015) found that companies engage in IFR for enhancing corporate image; showing their technology development; seeking share prices stability, and hoping to receive government support.

Kuruppu, Oyelere, and Al Jabri (2015) examined the use of the internet as a medium for the voluntary communication of financial information by publicly traded companies on the Colombo Stock Exchange (CSE) in Sri Lanka. Data of 244 companies from 20 industry sectors were analyzed. The results showed a low usage of internet medium by companies in Sri Lanka as well as a variety of reporting formats utilized for engaging in IFR. Groff and Pitman (2004) proposed three approaches that can be used by the companies to improve the financial section of their website which are as follows:

- Increasing the cases of using technological improvements and website design changes.
- Expanding the types of information provided including conference calls, transcripts, speech texts and slides, web casting conference calls, investor questions and answers and industry highlights.

- Observing other companies' websites occasionally in order to see what other firms are providing in their websites and to get ideas as what should be included in their own websites.

Singh and Singh (2015) analyzed the extent of financial disclosure by Indian public and private companies and investigated if any difference occurs between the two sectors. The result shows no significant differences between the two sectors related to utilizing their websites for financial disclosure, however, differences exist between the two sectors related to IFR practice. In short, with Internet financial reporting, communication with the investors is expected to be very effective and interactive and in turn adds real value to the stakeholders and facilitates the companies in controlling their marketplaces.

\section{The Determinants of Internet Financial Disclosure}

A large number of studies in different countries attempted to find out the determinants of the extent of financial disclosure (see e.g. Tariq, 2001; Da Silva \& De Lira, 2004; Hassan, Jaffer \& Johi, 1999; Khadaroo, 2005; Hossain \& Hammami, 2009; Cormier, Ledoux \& Magnan, 2012; Abdur Rouf \& Abdullah-Al Harun, 2011; Nekhili, Boubaker \& Lakhal, 2012; Hossain, Momin $\&$ Leo, 2012). They came up with different determinants and factors that might affect the extent of disclosure. These determinants could be in the form of internal determinants such as firm characteristics, or external determinants such as regulations and government roles. However, there was no consistency in the findings due to the different nature of studies. This encouraged the researcher to examine ten variables with IFD. These determinants are discussed in the following subsections. 


\section{Internationality}

When an organization becomes famous and known globally, the extent of its information disclosure will be increased due to the increase in foreign stakeholders and the obligation to fulfill different requirements and regulations in different countries (Meek, Roberts \& Gray, 1995). Meek, Roberts and Gray (1995) examined the annual reports of 280 multinational firms in 1989 and found that there were significant differences in financial reporting between international listed companies and local listed companies. The annual reports of multinational companies were more detailed than the annual reports of local companies. Similar results were obtained by Susanto (1992) who analysed the annual reports of 98 listed companies in the Jakarta Stock Exchange in 1990.

Raffournier (1995) found that the size and the degree of internationalization are related to disclosure practice. Foreign companies tend to comply with the rules of the countries in which they operate (Bureau \& Raffournier, 1989). Cooke (1992) supported this by saying that internationality is positively related to the extent of financial disclosure. The current study attempts to examine the impact of the internationality variable on IFD. The internationality is measured by using the exports-on-sales ratio (emulating Garcia \& Monterrey, 1992; Raffournier, 1995). Therefore, based on the above discussion, the proposed hypothesis to be tested is:

H1 : The extent of financial disclosure on the Internet is positively related to the level of international activity of the company

\section{Leverage}

The results of the impact of leverage on the extent of voluntary disclosure are mixed. Naser, AlKhatib and Kharbari (2002) and Laswad, Fisher and Oyelere (2005) found a positive relationship between them. It supported the argument that more debts in the company's financial capital pushed creditors to ask for more information due to higher asymmetry information (Cormier,
Ledoux \& Magnan, 2012). However, Chow and Boren (1987) and Ahmed and Nicholls (1994) found no significant association between them. Dichev and Skinner (2002) argued that the inconsistent results were due to the fact that leverage was a poor proxy for a company's risk. This study intends to examine the impact of external debt on the extent of financial performance amongst Malaysian companies. Previous studies have measured leverage in terms of debt to equity ratio (Roberts, 1992; Katsuhiko, Akihiro \& Al-Modhahki, 2001). Other studies measured leverage by comparing the total of long - term liabilities to the total of assets (Haniffa \& Cooke, 2002; Laswad, Fisher \& Oyelere, 2005; Alsaeed, 2005; Dâmaso \& Lourenço , 2011). In this study, leverage will be measured by using the percentage of long - term liabilities on the total assets. Based on the above discussion, the study proposed the following second hypothesis:

H2 : The extent of financial disclosure on the Internet is positively related to leverage

\section{Foreign Shareholders}

Haniffa and Cooke (2002) found a significant positive relationship between foreign ownership and the level of paper-based disclosure. The results supported the argument that the higher the foreign ownership in an organization, the higher the asymmetry information would be. This became critical if the regulations of the investment- received country were not understood. This in turn pushed foreign shareholders to ask for more information which was initially not required by the regulations and eventually led to more voluntary disclosure (Leung, Morris \& Gray, 2005).

However, Xiao, Yang and Chow (2004) found no significant relationship between foreign ownership and Internet disclosure by the companies in China. This discrepancy motivated the researchers to study the impact of foreign ownership on the extent of voluntary disclosure on the Internet in other countries. This variable is measured by using the ratio of total shares that 
are owned by foreigners to the total number of issued shares (Haniffa \& Cooke, 2002; Abdur Rouf \& Abdullah-Al Harun, 2011). Based on the above discussion, the proposed hypothesis to be tested is as follows:

\section{H3 : The extent of financial disclosure on the Internet is positively related to the existence of foreign shareholders.}

\section{Level of Technology}

The existence of technological services in the companies such as the department of technology are beneficial to them especially for Internet disclosure (Lodhia, 2004; Asmah Abdulaziz, Nur Nariza, \& Intan Salwani, 2011). The responsibility to maintain the website such as uploading and updating information on the website goes to the information technology department of the company. The website, unlike paper-based reporting, has many features and formats such as PDF, hyperlink, audio, video and others that require experts to operate there. This is to ensure that the website provides the needed information properly.

Although the cost to disclose information on the Internet is cheaper compared with other media, the web setting and maintaining it is costly (Joshi \& Jawaher, 2003; Lodhia, 2004) especially if it is outsourced. Therefore, information the technology department is important in order to reduce such costs and to attain an ideal information system practice. Debreceny, Gray and Rahman (2002) examined the association between the level of technology and the extent of voluntary disclosure through the Internet and found a significant positive relationship between them.

This study attempts to study the relationship between the extent of Internet financial disclosure and the level of technology in Malaysian - listed companies. The involved variable is measured by using a dummy measurement. Thus, the proposed hypothesis is as follows:

H4 : The extent of financial disclosure on the Internet is influenced by the level of technology.

\section{Firm Age}

There are a few studies that concentrate on time factor as a determinant of voluntary disclosure. For example, Haniffa and Cooke (2002) examined the impact of listing age on the level of voluntary financial disclosure amongst Malaysian - listed companies. The result was quite surprising whereby the variable showed a high positive correlation with disclosure but not with voluntary disclosure. A similar result was also obtained by Alsaeed (2005), and Hossain and Hammami (2009). Camfferman and Cooke (2002) in their study also suggested that the age of company might have a significant impact on the extent of Internet disclosure. This was also because of the expectation that old companies might improve their annual report and level of disclosure overtime.

In contrast, Hossain, Momin and Leo (2012) examined the impact of firm age on the internet financial and non-financial reporting and they found an insignificant relationship between the two variables. With the inconsistent results of firm age, this study aims to examine this variable by counting the number of operating years since the company was listed on the stock exchange. In other words, the impact of the firm age on the extent of Internet financial disclosure will be examined. The proposed hypothesis is as follows:

H5 : The extent of financial disclosure on the Internet is influenced by the firm age.

\section{Number of Shareholders}

Debreceny, Gray and Rahman (2002) argued that the external environment had an important role in the level of Internet disclosure. The level of internet usage by the public, and the environment of disclosure in the operating country are two important Internet disclosure determinants. For the first determinant, if the usage of the Internet is common in one country, the users expect more company information to be placed on the Internet (Dolinšek, Tominc \& Skerbinjek, 2014). Similarly, if the companies 
believe that there is a large Internet audience amongst their local stakeholders, they tend to disclose more information on the Internet. Oyelere, Laswad and Fisher (2003) found that spread of shareholding has a significant positive relationship with the extent of voluntary financial disclosure on the Internet by New Zealand - listed companies. However, Naser, AlKhatib and Karbhari (2002) found no significant relationship between the number of shareholders and the extent of voluntary disclosureTherefore, it is interesting to examine this variable in the Malaysian context, that is to test the impact of number of shareholders on the level of Internet disclosure. The following hypothesis is proposed:

H6 : The extent of financial disclosure on the Internet is influenced by the number of shareholders.

\section{Listing Status}

Wallace, Naser and Mora (1994) examined the impact of listing status on the level of voluntary disclosure amongst Spain - listed companies. Multivariate regression analysis was employed to analyze the data. The result showed a significant positive relationship between listing status and the extent of voluntary disclosure.

In Bursa Malaysia, ( in the Past) there were two types of listing boards; the main board and the second board. The main board companies had a minimum paid-up capital of Ringgit Malaysia (RM) 60 million while the second board companies are those that have a minimum paid-up capital of RM40 millions in capital in order to be qualified to be listed (Yatim, Kent \& Clarkson ,2006). The companies that did not meet the criteria of the main board could apply to be listed on the second board. Due to the difference in size and capital, the companies on the main board inclined to disclose more information on the Internet than those that were listed on the second board. This was due to the following reasons:

- The requirements that the company should fulfill if it wanted to be listed on the main board. Those requirements were not similar to that of the second board such as the level of transparency (Wong, 1996).

- $\quad$ The competition amongst the main board companies was stiffer than those on the second board as investors were keen on them (Abdul Samad, 2002).

Therefore it is interesting to examine whether the practising listing status of Bursa Malaysia has any influence on the level of Internet disclosure. In other words, this study examines the impact of an organization's listing status in Bursa Malaysia on the extent of voluntary financial disclosure on the Internet. Therefore, the following hypothesis is proposed:

\section{$H 7$ : The extent of financial disclosure on the Internet is influenced by the firm's listing status.}

\section{Dominant Personalities in the Audit Committee}

The role of the audit committee is critical in the decision - making process because it has the authority to examine sensitive issues and irregularities and give reports to the board with recommendations. The board ultimately makes decisions after examining the report meticulously. The primary objective of the audit committee is to assist the board of directors in fulfilling its responsibilities in relation to the accounting and reporting practices of the company and its subsidiaries, and to determine the adequacy of the company's administrative, operating and accounting controls (Haron, Jantan \& Pheng, 2005; Cohen, Gaynor, Krishnamoorthy \& Wright, 2007). The audit committee also reviews the adequacy and the effectiveness of corrective actions that are taken by the management in resolving reported audit issues and discusses the appropriateness of adopted accounting policies and treatment and assumptions that are raised by the external auditors (Collier, 1997; Hossain \& Hammami, 2009).

It is argued that if the chairman of the company holds several positions in the company's committees such as the audit committee, then the decision on disclosure will be affected 
significantly (Mangena \& Pike, 2004). The chairman may use his/her position to influence such decisions. This study attempts to provide empirical evidence regarding this issue by examining the extent of voluntary financial disclosure on the Internet if the chairman of the board of directors is also the chairman of the audit committee of the company. Thus the following alternative hypothesis is proposed:

H8 : The extent of financial disclosure on the Internet is influenced if the chairman of the board of directors is also the chairman of the audit committee in the company.

\section{Chairman of Audit and Nomination Committees}

The nominating committee has a number of duties and responsibilities that has to be fulfilled. The duties are such as reviewing annually the attendance and performance of the individual directors, reviewing the compensation of directors and making recommendations to the board of directors as to such compensation, recommending to the board of directors nominees who meet the criteria approved by the board of directors for nomination or election as directors, developing and overseeing corporate governance principles for the corporation and performing other duties that may be assigned to the committee by the board of directors over time (Vafeas, 1999). It is argued that if the chairman of the audit committee and the nominating committee are not the same person their independence might be enhanced as committee members are "Independent Directors" by virtue of the rules of the stock exchange, and in accordance with the corporate governance concepts and policies (Chtourou, Bedard \& Courteau, 2001).

As the audit and the nomination committees function as monitoring committees, and in turn influence the process of decision - making, an understanding of their roles in the financial disclosure on the Internet is considered critical. This study aims to examine this theoretical information in a real life setting. To ease this process, the following hypothesis is identified:
H9 : The extent of financial disclosure on the Internet is influenced if the chairman of the audit committee is also serving as the chairman of the nomination committee in the corporation.

\section{Dominant Personalities in the Audit and Nomination Committees}

As discussed above, there is a clear demarcation between the functions of the audit committee and the nomination committee. Each committee is responsible for critical and sensitive tasks and therefore must be separated. This is to ensure that the quality of the company's internal control is always at a satisfactory level. The chairman of the company, on the other hand, is responsible for ensuring that the board is always running effectively, the organizational members obtain relevant information and the company's policies are always observed. It is expected that if the chairman of the company is also the chairman of either the audit committee or the nomination committee or both, the decisions that are made in both the committees will be negatively affected (Shivdasani \& Yermack, 1999). This may include the decision on the extent of financial disclosure. Since this relationship has not been tested in previous studies, this research attempts to examine it from the perspective of the extent of financial disclosure on the Internet. Thus, the following hypothesis is proposed:

$H 10$ : The extent of financial disclosure on the Internet is influenced if the chairman of the board directors is also the chairman of the audit and the nomination committees in the company.

\section{Research Design}

\section{Simple selection}

This study concerns the financial disclosure on companies' websites. In Malaysia any 505 out of the 849 total listed companies (59 percent) have websites. A total of 200 companies which have 
websites were systematic randomly chosen after excluding banks and financial institutions due to their different regulations. Furthermore six companies were also excluded from the sample because they were identified as outliers in the initial analysis. Thus, data of 194 companies was used for the final analysis. The regression model was utilized to find out the results of this study and this was in tandem with previous studies (e.g. Chen \& Jaggi, 2000; Ho \& Wong, 2001; Camfferman \& Cooke, 2002; Archambault \& Archambault, 2003; Oyelere, Laswad \& Fisher, 2003; Marston \& Polei, 2004; Gul \& Leung, 2004; Laswad, Fisher, \& Oyelere, 2005; Hossain and Hammami, 2009; Agyei-Mensah, 2012).

\section{Descriptive Statistics}

The frequency for IFD index items (which was developed based on appendix 1) is shown in Table 1 . The table shows that $60 \%-63 \%$ of the companies disclose some financial information on the websites. About $62.9 \%$ of the companies disclose both current release or news and operation review items. Another $60.8 \%$ of the the companies disclose their annual reports and $58.8 \%$ of companies disclose financial highlight items. These are the most commonly disclosed items on the websites. This is followed by the annual reports for the past year $(51 \%)$, quarterly reports $(46.9 \%)$ and its contents such as statement of income, balance sheet, cash flow statement and accounting notes. However, only $12.4 \%$ and $7.7 \%$ of the companies are concerned with half year reports and performance charts respectively. As this information is critical for the investors, this finding shows a significant deficiency of the Malaysian - listed companies' financial reporting in the Internet.

\section{Results}

In tandem with previous studies of voluntary disclosure, (e.g. Cooke, 1989b; Hossain, tan \& Adams, 1994; Raffournier, 1995), and due to one dependent variable and ten independent variables, multiple regression analysis was used to test the hypotheses after adopting quality tests for normality, correlation analysis and multicollinearity. The results of the regression analysis show that several variables have significant positive relationships with IFD. These variables are level of technology, firm age, number of shareholders and listing status. However, the dominant personalities in the audit and nomination committees show a significant negative relationship with IFD. The rest of the variables do not show significant relationships with the extent of IFD (see Table 2).

\section{Discussion of Results}

The above results suggest that company's characteristic variables: level of technology, firm age, number of shareholders, listing status and the dominant personalities in the audit and nomination committees are significant variables for the extent of IFD in Malaysia. This finding is not surprising for several reasons. Firstly, since the paper investigated Internet disclosure (the most advanced technology in communication) it is expected that firms that have technology department are more likely to disclose more financial information through their websites. Secondly, old companies are more familiar with the disclosure practices through the Internet than newly established companies. Based on the signaling theory, old firms are generally disclosing more information in order to differentiate themselves from the new ones on the stock exchange (Morris, 1987; Watts \& Zimmerman, 1986; Skinner, 1994). In addition, as the old firms have more control over the market, they are in a better position to provide reliable forecasts (Hughes, 1986). Therefore, it is natural that an old company discloses more financial information than a new one. Thirdly, it is logical to observe that the number of shareholders is positively significant to IFD because the Internet has a wide coverage and low reporting cost when compared to other printing media. This advantage motivates the companies that have a large number of shareholders to use the Internet as a medium for disseminating their financial information.

The results of the regression analysis indicate that (as it was in the past Bursa Malaysia) if the companies are listed through the main board of Bursa Malaysia, they are more likely to have 
Table 1

The Internet Financial Disclosure Index (\%)

\begin{tabular}{|c|c|c|c|c|c|c|c|}
\hline $\mathrm{N}$ & $\begin{array}{l}\text { Financial } \\
\text { characteristics }\end{array}$ & Frequency & Percent & $\mathrm{N}$ & Financial characteristics & Frequency & Percent \\
\hline 1 & $\begin{array}{l}\text { Current release or } \\
\text { news }\end{array}$ & 122 & 62.9 & 9 & $\begin{array}{l}\text { Cash flow statement in } \\
\text { quarterly report }\end{array}$ & 80 & 41.2 \\
\hline 2 & Operation review & 122 & 62.9 & 10 & $\begin{array}{l}\text { Accounting notes in } \\
\text { quarterly report }\end{array}$ & 66 & 34 \\
\hline 3 & Annual report & 118 & 60.8 & 11 & Current share price & 47 & 24.2 \\
\hline 4 & $\begin{array}{l}\text { Financial } \\
\text { highlights }\end{array}$ & 114 & 58.8 & 12 & Financial review & 31 & 16 \\
\hline 5 & $\begin{array}{l}\text { Annual reports } \\
\text { for the past years }\end{array}$ & 99 & 51 & 13 & Financial calendar & 28 & 14.4 \\
\hline 6 & Quarterly report & 91 & 46.9 & 14 & Half - year report & 24 & 12.4 \\
\hline 7 & $\begin{array}{l}\text { Statement } \\
\text { of income in } \\
\text { quarterly report }\end{array}$ & 81 & 41.8 & 15 & Share Performance chart & 15 & 7.7 \\
\hline 8 & $\begin{array}{l}\text { Balance sheet in } \\
\text { quarterly report }\end{array}$ & 80 & 41.2 & & & & \\
\hline
\end{tabular}

Table 2

Multiple Regression Analysis of Determinants of Internet Financial Disclosure

\begin{tabular}{lcccc}
\hline Independent Variables & Predicted sign & Coefficients & t-statistics & VIF \\
\hline Company characteristics & & & & \\
Internationality & + & 0.053 & .947 & 1.061 \\
Leverage & + & 0.068 & 1.209 & 1.065 \\
Foreign shareholders & + & -0.049 & -.838 & 1.151 \\
Level of technology & + & 0.312 & $5.434 * * *$ & 1.118 \\
Firm age & + & 0.250 & $4.217 * * *$ & 1.191 \\
No of shareholders & + & 0.217 & $3.635 * * *$ & 1.207 \\
Listing status & + & 0.204 & $3.490 * * *$ & 1.156 \\
Dominant personalities in Board Committees & & & & \\
Chairman of company and audit committee & $?$ & -.051 & -.616 & 2.302 \\
Chairman of audit and nomination Committee & $?$ & .112 & 1.264 & 2.675 \\
Chair. Com, audit and nomination committees & $?$ & -.213 & $-3.355 * * *$ & 1.363 \\
Constant & & & -3.324 & \\
\hline
\end{tabular}

(continued) 


\begin{tabular}{|c|c|c|c|c|}
\hline Independent Variables & Predicted sign & Coefficients & $\mathrm{t}$-statistics & VIF \\
\hline ANOVA & 0.000 & & & \\
\hline Durbin Watson & 1.838 & & & \\
\hline Std.Error & 3.531 & & & \\
\hline F Value & 16.202 & & & \\
\hline Sig. F & 0.000 & & & \\
\hline R Square & 0.478 & & & \\
\hline Adjust R Square & 0.448 & & & \\
\hline
\end{tabular}

*** significant at $1 \%$ level $* *$ significant at $5 \%$ level $*$ significant at $10 \%$ level

The productive ability of analysis were $\mathrm{R}^{2}=478$ and Adjusted $\mathrm{R}^{2}=.448$ which is good.

websites and disclose more financial information on them when compared to the companies that are listed on the second board. In other words, there is a gap between the companies that are listed on the main board and the companies that are listed on the second board. This gap in turn, influences the level of transparency and the usage of advanced technology such as the Internet. Nevertheless, it is not surprising to observe this phenomenon because of the different requirements of Bursa Malaysia in relation to the main and the second boards. The difference is due to the fact that companies listed on the main board are big companies (financial capital of more than RM60 million), and therefore capture more public and government concern in relation to the level of transparency, technology development and environment. This results in the policy - makers of Bursa Malaysia to set more strict requirements and regulations for main board companies. Internet reporting is an option to fulfill all the requirements in cheap a and fast manner.

Last, but not least, the results of the regression analysis reveal that the level of IFD is negatively affected if the chairman of two committees (audit and nomination) is also the chairman of the company. In this case the chairman influences the independence of the two committees which in turn impedes them from fulfilling their responsibilities effectively. This is normally followed by a low level of information being disclosed.
From the analysis, it can be seen that significant support can be found for hypotheses H4, H5, H6, H7 and H10, However, there is no support for hypotheses $\mathrm{H} 1, \mathrm{H} 2, \mathrm{H} 3, \mathrm{H} 8$ and $\mathrm{H} 9$. Nevertheless, the information disclosed involves human judgment element, and therefore can never be explained completely by the company's characteristics. Within this context, however, the paper provides some evidence to support the signaling theory and the cost and benefit hypothesis in relation to disclosure.

\section{Conclusion and Future Research}

This paper examines the relationship between ten variables under two groups (company characteristics and dominant personalities in board committees) and the extent of IFD by Malaysian - listed companies. The results provide evidence that there is a significant positive relationship between each level of technology, firm age, number of shareholders, and listing status and the extent of IFD. However, the dominant personalities in the audit and nomination committees negatively affect the level of IFD. The other variables did not show any significant relationship with IFD. Therefore, it is recommended that the Malaysian government should give more consideration to the negative association of the extent of IFD and impose a new regulation that prohibits the executive directors from being the chairman or a member of audit committee in the company. 
It is also recommended that the establishment of the audit committee is mandatory for the listed companies. The criteria for the appointment of the chairman of the audit and the nomination committees should also be regulated.

It can be concluded that, there are number of procedures that the Malaysian government, policy - makers in the industrial sector, and regulatory authorities may take in order to enhance the level of transparency amongst the Malaysian - listed companies. The results of this group of independent variables provide the important characteristics in Malaysian companies that motivate them to be more transparent and be involved in high technology usage. The regulatory bodies have the opportunity to impose the necessary rules and regulations that obligate companies to take advantage of the Internet technology in the business area. This step seems to draw the guidelines for Malaysian - listed companies to be in the same direction with the government policy that seeks to achieve the developed country status in 2020 .

Due to time and cost limitations, this study is cross sectional and measures ten variables. Future research may undertake a panel study to examine whether these variables consistently have a significant influence on the extent of disclosure, since this research was carried out for one particular year only.

\section{References}

Abdul Samad, F. (2002). Ownership structure in the Malaysian corporation sector: Its impact on corporate governance, performance, financing and investment patterns. Institute for Development Policy and Management Working Paper (University of Manchester).

Abdur Rouf \& Abdullah-Al Harun. (2011). Ownership structure and voluntary disclosure annual reports of Bangladesh. Pak. J. Commer. Soc. Sci, 5(1), 129-139.

Ahmed, K., \& Nicholls, D. (1994). The impact of non-financial company characteristics on mandatory disclosure compliance in developing countries: The case of Bangladesh. The International Journal of Accounting, 29(1), 62-77.

Agyei-Mensah B. (2012). Corporate financial reporting: Firm characteristics and the use of Internet as a medium of communication by listed firms in Ghana. African Journal of Business Management, 6(6), pp.2299-2309.

Al-Htaybat Kh., Von L., Hutaibat kh. (2011). Users' perceptions on Internet financial reporting practices in emerging markets: Evidence from Jordan. International Journal of Business and Management, 6(9).

Ali Khan, M.N.A., Ismail, N. A., \& Zakuan, N. (2013). Benefits of internet financial reporting in a developing country: Evidence from Malaysia. African Journal of Business Management, 7(9), 719-726.

Ali Khan, M.N.A. \& Ismail, N.A. (2015).

Pandangan pelajar universiti terhadap pelaporan kewangan menerusi Internet. International Journal of Environment, Society \& Space, 3(1), 15-27.

Alsaeed, K. (2005). The association between firm-specific characteristics and disclosure: The case of Saudi Arabia. Managerial Auditing Journal, 21(5), 476-489.

Archambault, J. J., \& Archambault, M. A. (2003). A multinational test of determinants of corporate disclosure. The International Journal of Accounting, (38), 173-194.

Ashbaugh, H., Johnstone, K. M., \& Warfield, T. D. (1999). Corporate reporting on the Internet. Accounting Horizons, 13(3), 241-257.

Asmah AbdulAziz, Nur Nariza \& Intan Salwani Mohamed. (2011). Internet financial reporting in Malaysia. IPCSIT (3).

Botosan, C. A. (1997). Disclosure level and the cost of equity capital. ... Disclosure, liquidity and the cost of capital. Journal of Finance 46(4), 1325-1359.

Basuony, M.A.K., \& Mohamed, E.K.A. (2014). Determinants of Internet financial disclosure in GCC countries. Asian Journal of Finance \& Accounting, ISSN 1946-052X . 6 (1). 
Bureau, D., \& Raffournier, B. (1989). Some determinants of accounting choices for consolidated statements of French firms: The case of pension costs engagement. Paper presented at the 12th EAA congress, Stuttgart.

Camfferman, K., \& Cooke.T. E. (2002). An analysis of disclosure in the annual reports of UK and Dutch companies. Journal of International Accounting Research, (1), 3-30.

Chen, C. J. P., \& Jaggi, B. (2000). Association between independent non-executive directors, family control and financial disclosures in HongKong. Journal of Accounting and Public Policy, 19(4\&5), 285-310.

Chow, C. W., \& Boren, W. A. (1987). Voluntary financial disclosure by Mexican corporations. The Accounting Review, 62(3), 533-541.

Chtourou, S. M., Bedard, J., \& Courteau, L. (2001). Corporate governance and earnings management. Social Science Research Network.

Clarkson, M. B. E. (1995). A stakeholder framework for analyzing and evaluating corporate social performance. The Academy of Management Review, 20(1), 92-117.

Cohen, J., Gaynor, L. M., Krishnamoorthy, G., \& Wright, A. M. (2007). Auditor communications with the audit committee and the board of directors: Policy recommendations and opportunities for future research. ACCOUNTING HORIZONS, 21(2), 165.

Collier, P. (1997). Corporate governance and audit committees. Current Issues in Auditing.

Cooke, T. E. (1989b). Voluntary corporate disclosure by Swedish companies. Journal of International Financial Management and Accounting, (1), 171195.

Cooke, T. E. (1992). The impact of size, stock market listing and industry type and disclosure in the annual report of japanese listed corporations. Accounting and Business Research, (87), 221-237.
Cormier. D., Ledoux MJ., \& Magnan M. (2012). The moderating effect of voluntary disclosure on the relation between earnings quality and information asymmetry: Some Canadian evidence. International Journal of. Accounting, Auditing and Performance Evaluation, $8(2)$.

Da Silva, W. M., \& de Lira Alves, L. (2004). The voluntary disclosure of financial information on the Internet and the firm value effect in companies across Latin America. 13th International Symposium on Ethics, Business and Society, January.

Dâmaso, G., \& Lourenço, I. C. (2011). Internet financial reporting: Environmental impact companies and other determinants. $8^{\text {th }}$ International Conference on Enterprise Systems, Accounting and Logistics ( $8^{\text {th }}$ ICESAL 2011)11-12 July 2011, Thassos Island, Greece

Dolinšek, T., Tominc, P., \& Skerbinjek, A. L. (2014). Users' perceptions on Internet financial reporting. organizacija, 47, 254-266.

Debreceny, R., Gray G. L., \& Rahman, A. (2002). The determinants of Internet financial reporting. Journal of Accounting and Public Policy, 21, (4\&5), 371-394.

Diamond, D., \& Verrecchia, R. (1991). Disclosure, liquidity and the cost of equity capital. Journal of Finance, (44), 1325-1360.

Dichev, L., \& Skinner, D. (2002). Large-sample evidence on the debt covenant hypothesis. Journal of Accounting Research, 40(4), 1091-1124.

Ettredge, M., Richardson, V. J., \& Scholz, S. (2002). Dissemination of information for investors at corporate Websites. Journal of Accounting and Public Policy, 21(45), 357-369.

Frankel, R., Johnson, M., \& Skinner, D. J. (1999). An empirical examination of conference calls as a voluntary disclosure medium. Journal of Accounting Research, 37(1), 133-150.

Garcia-Benau , M. A., \& Monterrey- Mayoral, J. (1992). Voluntary financial disclosure by listed Spanish companies: Extent 
and corporate characteristics. Paper presented at the the 15th EAA congress, Madrid.

Groff, J.E., \& Pitman, M. K. (2004). Municipal financial reporting on the World Wide Web: A survey of financial data displayed on the official websites of the 100 largest U.S. municipalities. The Journal of Government Financial Management, 2(53), 2-22.

Gul, F. A., \& Leung, S. (2004). Board leadership, outside directors' expertise and voluntary corporate disclosures. Journal of Accounting and Policy, 23(5), 351-379.

Hamdan, A., Al-sartawi, Abd al Muttaleb M., \& JaberRaed, J. (2013). The Effect of Corporate Governance on the Financial and Operational Performance and its Effect on Stock Performance in the Kuwait Stock Exchange. Arab Journal of Administrative Sciences. 20(2), 255.

Haniffa, R., \& Cooke, T. (2002). Culture, corporate governance and disclosure in Malaysian Corporations. ABACUS, 38(3), 317-349.

Haron, H., Jantan, M., \& Pheng, E. G. (2005). Audit committee compliance with Kuala Lumpur stock exchange listing requirements. International Journal of Auditing, 9(3), 187-200.

Hassan, A., Jaffer, N., \& Johi, S. K. (1999). Financial Reporting on the Interent By Malaysian Companies: Perceptions and Practices. Asia-Pacific Journal of Accounting, 6(2), 299-319.

Ho, S. S. M., \& Shun Wong, K. (2001). A study of the relationship between corporate governance structures and the extent of voluntary disclosure. Journal of International Accounting, Auditing and Taxation, 10(2), 139-156.

Hossain, M., Tan, L. M., \& Adams, M. (1994). Voluntary disclosure in an emerging capital market: some empirical evidence from companies listed on the KualaLumpur Stock Exchange. The International Journal of Accounting, (4), 334-351.

Hossain, M., \& Hammami, H. (2009). Voluntary disclosure in the annual reports of an emerging country: The case of Qatar; Advances in Accounting, incorporating Advances in International Accounting, 25. 255-265.

Hossain, M., Momin, M.A., \& Leo, S. (2012). Internet financial reporting and disclosure by listed companies: Further evidence from an emerging country. Corporate Ownership and Control. 9(4), 350-366.

Hughes, P. J. (1986). Signalling by direct disclosure under asymmetric information. Journal of Accounting and Economics 8(2), 119-142.

Hurtt, D. N., Kreuze, J. G., \& Langsam, S.A. (2001). Using the Internet for financial reporting. The Journal of Corporate Accounting \& Finance, 12(3), 67-75.

Joshi. P.L, \& Jawaher Al-Modhahki. (2003). Financial Reporting on the Internet: Empirical evidence from Bahrain and Kuwait. Asia Review of Accounting, (11), 88-101.

Katsuhiko, K., Akihiro, N., Yasushi, O., \& Tomomi, S. (2001). Determinants of Environmental Report Publication in Japanese Companies. Paper presented at the the third APIRA conference, Adelaide Australia.

Khadaroo, M. I. (2005). Business reporting on the Internet in Malaysia and Singapore, A comparative study. Corporate Communications; an International Journal, 10(1), 58-68.

King, R., Pownall, G., \& Waymire, G. (1990). Expectation adjustment via timely management forecasts: Review synthesis and suggestions for future research. Journal of Accounting Literature.

Kuruppu, N., Oyelere P., \& Al Jabri, H., (2015) Internet Financial Reporting And Disclosure Practices Of Publicly Traded Corporations: Evidence From Sri Lanka., Accounting \& Taxation. Vol (7), 75-91.

Lang, M. H., \& Lundholm, R. J. (1996). Corporate disclosure policy and analyst behavior. The Accounting Review, 71(4), 467-492.

Laswad, F., Fisher, R., \& Oyelere, P. (2005). Determinants of voluntary Internet 
financial reporting by local government authorities. Journal of Accounting and Public Policy, 24(2), 101-121.

Leung., Morris, R. D., \& Gray, S.J. (2005). Corporate transparency in china: factors influencing financial disclosure levels.

Levitt, A. (1999). Quality Information: The Lifeblood of Our Marketing. The Economic Club of New York.

Lodhia, S. K. (2004). Corporate environmental reporting media: A case for the world wide web. Electronic Green Journal(20).

Mangena, M., \& Pike, R. (2004). Shareholding of audit committee members, audit committee size and expertise, and the quality of interim financial reporting: mimeo: Bradford.

Marston, C., \& Polei, A. (2004). Corporate reporting on the Internet by German companies. International Journal of Accounting Information Systems, 5(3), 285- 311 .

Meek, G. K., Roberts, C. B., \& Gray, S. J. (1995). Factors influencing voluntary annual report disclosures by US, UK and continental european multinational corporations. Journal of International Business Studies, 26(4).

Mitchell, W., Ho, Wern., \& Pei, C. (2000). Corporate social disclosures by listed companies on their websites: An international comparison. HongKong, China: Hong Kong Polytechnic University.

Moonitz, M. (1961). The basic postulates of accounting. Accounting Research Study, AICPA.New York, 1.

Morris, R. D. (1987). Signalling, agency theory and accounting policy choice. Accounting and Business Research, 18(69), 47-56.

Naser, K., Al-Khatib, K., \& Karbhari, Y. (2002). Empirical evidence on the depth of corporate information disclosure in developing countries: The Case of Jordan. International Journal of Commerce and Management, 12(3), 122-155.

Noor Azizi, Mahamad, T., \& Adon, I. (2000). Financial reporting disclosure on the Internet by Malaysian - listed companies. Akauantan Nasional 1(1), 28-33.

Nekhili, M., Boubaker, S., \& Lakhal, F. (2012).
Ownership Structure, Voluntary R\&D Disclosure and Market Value of Firms: The French Case. International journal of business, 17(2), 2012 ,ISSN: 1083 4346

Oyelere, P., Laswad, F., \& Fisher, R. (2003). Determinants of internet financial reporting by New Zealand companies. Journal of International Financial Management and Accounting, 14(1), 2663.

Portes, R., \& Rey, H. (2005). The determinants of cross-border equity flows. Journal of International Economics, 65(2), 269296.

Raffournier, B. (1995). The determinants of voluntary financial disclosure by Swiss listed companies. The European Accounting Review, 4(2), 261-280.

Richardson, A. J., \& Welker, M. (2001). Social disclosure, financial disclosure and the cost of equity capital. Accounting Organizations and Society, 26(7), 597616.

Roberts. (1992). Determinants of corporate social responsibility disclosure: An application of stakeholder theory. Accounting, Organizations and Society, 17(6), 595-612.

Rosli Mohammed, Amdan Mohamed, \& Mohamed, M. (2003). Internet financial reporting (IFR) in Malaysia;- A survey of contents and presentations University Utara Malaysia.

Sanad, Z. R., \& Al-Sartawi, A . M., (2016) Investigating the Relationship between corporate governance and Internet financial reporting (IFR): Evidence from Bahrain Bourse. Jordan Journal of Business Administration, 12(1).

Shivdasani, A., \& Yermack, D. (1999). CEO involvement in the selection of new board members: An empirical analysis. The Journal of Finance, 54(5), 18291853.

Singh, H., \& Singh, A. (2015). Internet Financial Reporting by Indian Public and Private Companies. Journal of Marketing and $H R,(1), 25-32$.

Skinner, D. J. (1994). Why firms voluntary 
disclose bad news. Journal of Accounting Research, (32), 38-60.

Susanto, D. (1992). An empirical investigation of the extent of corporate disclosure in annual reports of companies listed on the Jakarta stock exchange University Microfilms International.

Tariq, H. I. (2001). An empirical investigation of factors influencing voluntary disclosure of financial information on the Internet in the GCC countries. Qatar University.

Vafeas, N. (1999). The nature of board nominating committees and their role in corporate governance. Journal of Business Finance \& Accounting, 26(12), 199-225.

Verawaty. (2016). The comparative analysis of accessibility index value of government Internet financial reporting In Indonesia. Applied Finance and Accounting, 2(2).

Watts, R. L., \& Zimmerman, J. L. (1986). Positive accounting theory. Englewood Cliffs, New Jersey.

Wheeler, D., \& Elkington, J. (2001). The end of the corporate environmental report? Or the advent of cybernetic sustainability reporting and communication. Business Strategy and the Environment, (10), 1-14.

Wong, N. L. (1996). Easing down the meritdisclosure continuum: A case study of Malaysia and Taiwan. Law and Policy in International Business, 28(1).

Xiao, J. Z., Yang, H., \& Chow, C. W. (2004). The determinants and characteristics of voluntary Internet-based disclosures by listed Chinese companies. Journal of Accounting and Public Policy, 23(3), 191-225.

Yatim, P., Kent, P., \& Clarkson, P. (2006). Governance structures, ethnicity, and audit fees of Malaysian - listed firms. Managerial Auditing Journal, 21(7), 757-782.

Yeo, G. H. H., \& Ziebart, D. A. (1995). An empirical test of the signaling effect of management's_earnings forecasts: A decomposition of the earnings surprise and forecast surprise effects. Journal of Accounting, Auditing \& Finance, 10(4), 787-802. 
Malaysian Management Journal Vol. 20, December 2016 59-75

Appendix ( A): Index Items of financial information disclosed on the Internet

\begin{tabular}{|c|c|c|c|c|c|c|c|c|c|c|c|}
\hline $\mathrm{N}$ & Items & A & B & $\mathrm{C}$ & $\mathrm{D}$ & $\mathrm{E}$ & $\mathrm{F}$ & G & $\mathrm{H}$ & I & $\mathrm{J}$ \\
\hline 1 & Financial highlights & 1 & & & 1 & 1 & 1 & 1 & 1 & & \\
\hline 2 & Current press release or news & 1 & 1 & 1 & 1 & & 1 & 1 & & & \\
\hline 3 & Current share price & 1 & 1 & 1 & 1 & & 1 & 1 & & & \\
\hline 4 & Share performance chart & & & & & & & & & 1 & \\
\hline 5 & Operation review & & & & & & & & & 1 & \\
\hline 6 & Financial review & & & & 1 & & & & & & 1 \\
\hline 7 & Financial calendar & & & & 1 & & & & & & 1 \\
\hline 8 & Annual report & & & 1 & 1 & & 1 & 1 & & & \\
\hline $8-1$ & Directors and management report & & 1 & 1 & & 1 & 1 & 1 & 1 & & \\
\hline $8-2$ & Balance sheet & 1 & 1 & 1 & 1 & 1 & 1 & 1 & 1 & & \\
\hline $8-3$ & Income statement & 1 & 1 & 1 & 1 & 1 & 1 & 1 & 1 & & \\
\hline $8-4$ & Cash flow statement & 1 & 1 & 1 & 1 & 1 & 1 & 1 & 1 & & \\
\hline $8-5$ & Statement of shareholders' equity & & & & & 1 & 1 & 1 & 1 & & \\
\hline $8-6$ & Accounting notes & 1 & 1 & 1 & 1 & 1 & 1 & 1 & 1 & & \\
\hline $8-7$ & Auditor's report & & 1 & 1 & 1 & 1 & 1 & 1 & 1 & & \\
\hline $8-8$ & Segmental report by region & & & 1 & & & 1 & 1 & & & \\
\hline $8-9$ & Shareholder structure & & & & & & 1 & & & & \\
\hline 9 & Annual report for the past years & & & & & & 1 & 1 & & & \\
\hline 10 & Half year report & 1 & 1 & & & & 1 & 1 & & & \\
\hline 11 & Quarterly report & & & & 1 & & & 1 & & & \\
\hline 12 & Balance sheet in quarterly report & & & & & & & 1 & 1 & & \\
\hline 13 & Statement of income in quarterly report & & & & & & & 1 & 1 & & \\
\hline 14 & Cash flow statement in quarterly report & & & & & & & 1 & 1 & & \\
\hline 15 & Accounting notes in quarterly report & & & & & & & 1 & 1 & & \\
\hline
\end{tabular}

A = Deller et al. (1999), B= Pirchegger and Wagenhofer (1999), C= Debreceny et al. (2002), D= Ettredge et al.(2002), E= Marston (2003), F= Marston and Polei (2004), G=Xiao, Yang, Chow (2004), H= Alarussi (2005), I= Fathilatul (2005), J= Menes-Da-Silva and Christencen (2004).

ndex Items of financial information disclosed on the Internet

\begin{tabular}{ccc}
\hline $\mathrm{N}$ & Items & Overlap with prior studies \\
\hline 1 & Financial highlights & $\mathrm{A}, \mathrm{D}, \mathrm{E}, \mathrm{F}, \mathrm{G}, \mathrm{H}$ \\
2 & Current press release or news & $\mathrm{A}, \mathrm{B}, \mathrm{C}, \mathrm{D}, \mathrm{F}, \mathrm{G}$ \\
3 & Current share price & $\mathrm{A}, \mathrm{B}, \mathrm{C}, \mathrm{D}, \mathrm{F}, \mathrm{G}$ \\
4 & Share performance chart & $\mathrm{I}$ \\
5 & Operation review & $\mathrm{I}$ \\
6 & Financial review & $\mathrm{D}, \mathrm{J}$ \\
7 & Financial calendar & $\mathrm{D}, \mathrm{J}$ \\
8 & Annual report & C,D,F,G \\
\hline
\end{tabular}

(continued) 
Malaysian Management Journal Vol. 20, December 2016 59-75

\begin{tabular}{ccc}
\hline N & Items & Overlap with prior studies \\
\hline $8-1$ & Directors and management report & B,C,E,F,G,H \\
$8-2$ & Balance sheet & A,B,C,D,E,F,G, H \\
$8-3$ & Income statement & A,B,C,D,E,G,H \\
$8-4$ & Cash flow statement & A,B,C,D,E,G,H \\
$8-5$ & Statement of shareholders equity & E,F,G,H \\
$8-6$ & Accounting notes & A,B,C,D,E,F,G,H \\
$8-7$ & Auditor's report & B,C,D,E,F,G,H \\
$8-8$ & Segmental report by region & C,F,G \\
$8-9$ & Shareholder structure & F \\
9 & Annual report for the past years & F,G \\
10 & Half year report & D, , F , \\
11 & Quarterly report & G, H \\
12 & Balance sheet in quarterly report & G, H \\
13 & Statement of income in quarterly report & G, H \\
14 & Cash flow statement in quarterly report & G, H \\
15 & Accounting notes in quarterly report & \\
\hline
\end{tabular}

$\mathrm{A}=$ Deller et al. (1999), B= Pirchegger and Wagenhofer (1999), $\mathrm{C}=$ Debreceny et al. (2002), $\mathrm{D}=$ Ettredge et al.(2002), E= Marston (2003), F= Marston and Polei (2004), G=Xiao, Yang, Chow (2004), H= Alarussi(2005), $\mathrm{I}=$ Fathilatul (2005), J= Menes-Da-Silva and Christencen (2004). 